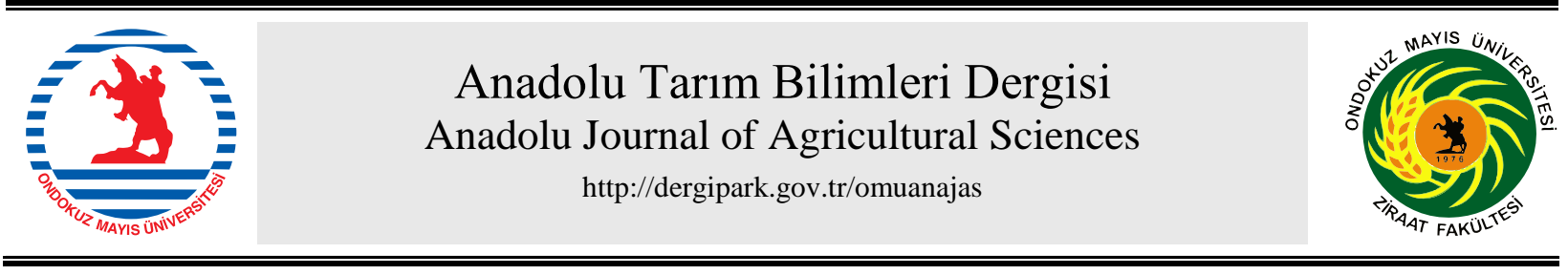

Araştırma/Research

Anadolu Tarım Bilim. Derg./Anadolu J Agr Sci, 36 (2021)

ISSN: 1308-8750 (Print) 1308-8769 (Online)

doi: 10.7161/omuanajas.773460

\title{
TR71 Bölgesinde İşletmelerin Koyun Yetiştiriciliği Faaliyetine Devam Etme Olasılığını Etkileyen Faktörlerin Analizi
}

\author{
@Betül Gürer ${ }^{a^{*}}$, ®Zafer Ulutaş ${ }^{\mathrm{a}}$ \\ ${ }^{a}$ Niğde Ömer Halisdemir Üniversitesi, Tarım Bilimleri ve Teknolojileri Fakültesi, Hayvansal Üretim ve Teknolojileri Bölümü, Niğde, Türkiye
}

*Sorumlu yazar/corresponding author: bgurer@ohu.edu.tr

Geliş/Received 27/07/2020 Kabul/Accepted 16/12/2020

\begin{abstract}
ÖZET
Türkiye'de son yıllarda hayvancılığa yönelik sağlanan desteklemelerle koyun varlığındaki azalma durdurulmasına rağmen, koyunculuk faaliyeti geleneksel yapısı içerisinde kayda değer bir gelişme gösteremeden sürdürülmeye çalışılmaktadır. Bu durum ise sektörün ekonomik faktörler dışında sürdürülebilirliğini sağlamada etkili olan diğer faktörlerin de araştırılması gerekliliğini ortaya koymaktadır. Bu çalışmanın amacı, TR71 bölgesinde Niğde ve Aksaray illerindeki yetiştiricilerin koyunculuk faaliyetine devam etme istekliliklerine etkili olan ekonomik, çevresel ve demografik faktörlerin belirlenmesi ve sektörün gelişimine yönelik alınacak politika önlemlerinin ortaya konulmasıdır. Çalışma kapsamında bölgede hayvan varlığının üçte ikisinden fazlasını oluşturan Niğde ve Aksaray illerinden 114 işletmeden yüz yüze anket yoluyla toplanan veriler kullanılmıştır. Yetiştiricilerin koyunculuk faaliyetini devam ettirme olasılıklarına etkili olan faktörleri ise lojistik regresyon yöntemiyle belirlenmiştir. Model sonuçları, işletmecilerin koyun yetiştiriciliğini devam ettirme olasılıklarına etkili faktörler; barınak koşullarının iyileştirilmesi, faaliyetin karlılı̆̆ durumu, yem bitkisi yetiştirme durumu ve çoban bulma sorunu olarak bulunmuştur. İşletmelerinde hayvan barınak ve/veya çalışanların konaklama yerlerini iyileştirenlerin koyunculuk faaliyetini devam ettirme olasılığı diğerlerine göre 14.01 kat daha fazladır. Diğer yandan nispi karlılığın bir birim artması işletmecilerin bu faaliyeti devam etme olasılığını 9.53 kat, evlilerin bekârlara göre koyun yetiştiriciliğini devam ettirme olasılığı 5.03 kat daha fazla olduğu bulunmuştur. Yem bitkisi yetiştiren işletmelerin yetiştirmeyenlere göre bu faaliyeti devam ettirme olasılığ 4.14 kat daha fazladır. Buna karşın, çoban bulmada sorun yaşayanların yaşamayanlara göre koyunculuk faaliyetini devam ettirme olasılığ $\% 81.1$ daha düşüktür. İşletmelerin koyunculuk sektörüne devam etmeleri, sektöre yönelik sosyal ve çevresel koşulların iyileştirilmesiyle birlikte işletmelerin yapısal koşullarını iyileştirecek destekleme önlemlerinin uygulanmasinı gerektirmektedir.
\end{abstract}

Analysis of the factors affecting the farms’ probability continuing sheep farming in the TR71 Region
ABSTRACT
Despite of preventing in the reduction of sheep numbers in Turkey during the recent years by means of the livestock supports, the sheep breeding activity has been tried to sustain within its traditional structure without performing a notable development. This situation reveals the necessity to investigate effective factors in ensuring the sustainability of the sector besides economic factors. This study aims to determine influencing economic, environmental and social factors on the producers' willingness to continue their sheep-breeding activities in the TR71 region and to provide a guide for policy decision makers for the development of the sector. The primary data of this study was collected from 114 sheep farms by conducting face to face interviews in Niğde and Aksaray provinces, which constitute more than two thirds of the animal numbers in the region Logistic regression method was used to estimate the likelihood of farmers' willingness to continue sheep farming. According to the study results, the improvement of

Anahtar Sözcükler: Koyun yetiştirciliği Tarımda kalma ve çıkma eğilimi TR71 bölgesi
Keywords: Sheep farming Tendency of stay or exit in agriculture TR71 Region 
conditions in sheep barn and/or accommodation for shepherd, profitability of the activity, marital status of the farmer, forage production and the lack of shepherd were found as the effective factors on the likelihood of the farmers' willingness to continue their sheep breeding activities. The farmers who improved sheep barn and/or accommodation for shepherd were 14.01 times more likely to continue the sheep farming. Accordingly, one unit increase in the relative profitability increased the likelihood of farmers 'willingness to continue sheep farming by 9.53 times. Similarly, married farmers were 5.03 times more likely to continue sheep farming than single farmers. Farmers who produced forage crops were 4.14 times more likely to continue sheep farming. On the other hand, farmers who had the problem of finding shepherds were $81.1 \%$ less likely to continue sheep farming. Continuation of the sheep farming sector requires the implementation of support measures that will improve the structural conditions of the enterprises, together with the improvement of the social and environmental conditions for the sector.

\section{Giriş}

Hayvansal üretim, Türkiye'nin tarım sektöründe aile iş gücünü en fazla değerlendirebilen, katma değeri yüksek, nüfusun yeterli ve dengeli beslenmesine önemli katkılar sağlayan bir alt sektördür. Hayvancılık içerisinde yer alan küçükbaş hayvan yetiştiriciliği, önemli bir ekonomik değer yaratmasının yanı sıra uzun yıllarca yürütüldüğü coğrafyada önemli bir sosyal ve kültürel birikime de sahiptir. Türkiye'deki mera alanlarının varlığı, kırsal kesimdeki ailelerin tüketim alışkanlıkları gibi etmenler, küçükbaş hayvan yetiştiriciliği için uygun bir ortam oluştururken, özellikle küçük aile işletmelerinin gelir kaynaklarının çeşitlendirilmesi ve bitkisel üretim alanlarının daha rantabl olarak değerlendirilmesi açısından önemli bir üretim alanıdır.

TÜIK'in 2019 yılı verilerine göre Türkiye'deki 48.5 milyon baş küçükbaş hayvan varlığının \%76.9'unu koyun varlığı oluşturmaktadır (TÜIK, 2020). Türkiye, koyun varlığı bakımından dünyada sekizinci sırada, AB'nde ise İngiltere'den sonra ikinci sırada yer almaktadır (FAO, 2020). Türkiye koyun yetiştiriciliği bakımından büyük bir potansiyele sahip olmasına rağmen, bir asra yakın süredir sektörde kayda değer bir gelişme sağlanamamış, hatta son 30 yıldaki koyun varlığı \%7.8, kesilen hayvan sayısı ise \%36.2 azalmıştır (TUİK, 2020). Benzer durum, Türkiye’nin koyun varlığının \%4.63'üne sahip TR71 bölgesinde de geçerli olmuştur. TR71 Bölgesi sahip olduğu dağlar, ovalar, çayır, mera ve otlaklar bakımından hayvancılık açısından uygun bir bölgedir. Bölgenin özellikle Niğde ve Aksaray illerinde, küçükbaş hayvan yetiştiriciliği konusunda yaygın bir kültür bulunmaktadır.

Türkiye'de özellikle 2000 yılında uygulamaya konulan "Hayvancılı̆̆ın Desteklenmesi Hakkında Bakanlar Kurulu Kararı" sonrasında hayvan sayısında yaşanan azalma eğilimi tersine çevrilebilmiştir. Bu dönemde Türkiye'de koyun varlığ 28.5 milyon baştan 1.47 kat artarak 37.3 milyon başa yükselmiştir. Benzer şekilde TR71 Bölgesindeki koyun varlığı da, 1.11 milyon baştan 1.72 kat artarak 1.73 milyon başa ulaşmıştır. 2000-2019 yılları arası dönemde Aksaray ilinin bölgenin koyun varlığındaki payı \%32.11'den (358 bin baş) \%38.92'ye (672 bin başa) yükseltmiştir. Buna karşın, Niğde ilinin koyun varlığındaki payı \%39.16'dan \%29.96'a düşmüştür (TÜİ, 2020).

Türkiye'de küçükbaş hayvancılık sektörüne sağlanan desteklerle sektörün karlılığı korunmaya çalış1lsa da arzu edilen hedeflere yeterince ulaşılamamıştır. Dünya ve Türkiye'de tarımın diğer alanlarında yaşanan teknolojik gelişmeler koyunculuk sektörüne yeterince yansıtılamamış ve halen geleneksel yetiştiricilik yapısı devam ettirilmektedir. Koyunculuk sektörü, karşı karşıya olduğu başta ekonomik problemler olmak üzere sosyal ve çevresel etkenlerden dolayı üreticiler için cazibesini yitirmektedir. Bu durum, desteklere bağlı halde ayakta tutulmaya çalışılan bu sektörün ekonomik faktörler dişında sürdürülebilirliğini sağlamada etkili olan diğer faktörlerin de araştırılması gerekliliğini ortaya koymaktadır.

Çiftçi davranışları, ekonomik, sosyal, kültürel, politik ve coğrafi olmak üzere oldukça fazla faktörden etkilenmektedir (Uysal, 2015). Kırsal kesimde başlıca ekonomik aktör durumundaki çiftçinin ekonomik kararlar alırken rasyonelliğin ötesinde davranışsal ögelerin daha çok etkisi bulunmaktadır. Bu durumun nedenleri arasında ataerkil aile biçiminin kırsalda varlığını hala önemli ölçüde sürdürmesi, üretim sisteminin doğaya bağlılığı, insanlar arası ilişki ve etkileşim sistemlerinin özgünlüğü gibi faktörler yer almaktadır. Tüm bunlar, ilgili etkin işletmecilik ve politika önerileri geliştirilebilmesi için kırsaldaki tutum ve davranışların dikkatle incelenmesi gerektiğini ortaya koymaktadır.

Literatürde hem gelişmiş hem de az gelişmiş ya da gelişmekte olan ülkeler için üreticilerin tarımsal faaliyetlerini sürdürmede etkili faktörleri ele alan çok sayıda araştırma bulunmaktadır. Bu çalışmalar arasında Kimhi ve Bollman (1999) Kanada ve İsrail'de, Pietola ve ark. (2003) Finlandiya'da, Breustedt ve Glauben (2007) Bat1 Avrupa'da, Mishra ve ark. (2014) ABD'de, Agrawal ve Agrawal (2017) Hindistan'da, Ahmad ve ark. (2020) Pakistan'da, Pokhrel ve ark. (2020) Nepal'de çiftçilerin tarımsal faaliyeti sürdürme veya bırakmada etkili çeşitli faktörleri ele almışlardır. Türkiye'de ise konuyla ilgili Sav ve Sayın (2018) çalışmalarında tarımın çok boyutluluğunu dikkate alarak çiftçilerin tarımsal faaliyetlerini sürdürmede etkili faktörleri ikincil verilerle incelemişlerdir. Başer ve ark. (2017) ise çalışmalarında işletme düzeyinde tarımın sürdürülebilirliğinin ölçülmesinde kullanılabilecek ekonomik, sosyal ve 
çevresel göstergeleri incelemişlerdir. Bölgesel düzeyde yapılan çalışmalarda Çukur (2016) tarafindan Milas ilçesinde ve Koç ve Uzmay (2019) tarafindan Trakya bölgesinde üreticilerin süt sığırcılığı faaliyetinden vazgeçme olasılığını etkileyen faktörler, Aksoy ve Yavuz (2012) Doğu Anadolu Bölgesi’nde küçükbaş hayvan yetiştiriciliğini bırakma nedenlerini, Bozoğlu vd. (2017) Samsun İli Bafra İlçesindeki aile süt sığırcılığı işletmelerinin ekonomik sürdürülebilirliğini, Keskinkılıç (2019) İzmir ilinde koyunculuk faaliyetinin sürdürülebilirliğini, Kan ve ark. (2018) ise TR71 bölgesinde genç çiftçi desteklemeleri kapsamında gençlerin tarımda kalma eğilimlerini incelemişlerdir. Bununla birlikte Türkiye ve TR71 bölgesinde koyunculuk faaliyetinin sosyo-ekonomik ve yapısal özelliklerine yönelik çalışmalar (Dağıstan, 2002; Şahinli, 2011; Koca, 2014; Ceyhan ve ark., 2015; Özsayın ve Everest, 2019) bulunmaktadır. Ancak koyunculuk faaliyetinin sürdürülebilirliğinin sağlanmasına yönelik sektörün tüm boyutlarını dikkate alarak etkili faktörlerin belirlenmesine yönelik bir çalışmaya rastlanılmamıştır. Bu çalışma, literatürdeki var olan boşluğun doldurulmasına katkı sağlayabilecektir. Bu çalışmanın amacı, TR71 bölgesindeki koyunculuk işletmelerinin koyun üretim faaliyetini gelecekte devam ettirmelerine etkisi bulunan faktörlerin olasılıkları ve bu konuda alınması gereken önlemlerin ortaya konulmasıdır.

\section{Materyal ve Yöntem}

Düzey 2 İstatistiki Bölge Birimi Sınıflaması (IBBBS)'na göre TR71 Bölgesi; Kırıkkale, Aksaray, Niğde, Nevşehir ve Kırşehir illerinden oluşmaktadır. Çalışmanın ana materyalini, TR71 bölgesindeki koyun varlığının \%68.9'unub bulunduğu Niğde ve Aksaray illerindeki koyunculuk yapan işletmeler arasından örneğe seçilen 114 işletmeden yüz yüze yapılan anket görüşmelerinden elde edilen birincil veriler oluşturmuştur. Araştırma alanının belirlenmesi ve örnekleme çalışmasının yapılabilmesi için Damızlık Koyun ve Keçi Yetiştiricileri Birliği kayıtlarından, araştırma alanına dahil olan illerde koyun yetiştiriciliği yapan tarım işletmelerinin sahip oldukları koyun sayıları listesi çıkartılmıştır. İşletmelerin sahip olduğu koyun sayısı örnekleme kriteri olarak kullanılmıştır. İşletmelerin sahip oldukları hayvan sayılarına ait varyasyonun yüksek olması nedeniyle, her bir tabakadan örneğe girecek işletme sayısının belirlenmesinde tabakalı örnekleme yönteminden yararlanılmıştır. Tabakalandırma işleminden sonra her tabakadan örneğe çıkacak işletme sayısının ya da örnek hacminin belirlenmesinde "Neyman" yöntemi kullanılmıştır (Yamane, 1967).

$$
n=\frac{\sum(N h S h)^{2}}{N^{2} D^{2}+N h S h^{2}}
$$

Eşitlik 1'deki n örnek hacmini, Nh; h'ıncı tabakadaki toplam işletme sayısını (frekans), Sh; h'ıncı tabakanın standart sapmasını, $N$ toplam işletme sayısı, D ortalamadan sapmanın (d) t dağılım çizelgesindeki t değerine $(Z)$ oranını ifade etmektedir. Araştırmadaki örnek hacminin belirlenmesinde $\% 10$ hata ve $\% 99$ güvenilirlik sinırları içerisinde çalışılmıştır. Populasyonu temsil edecek örnek işletme sayısı, Niğde ilinden 57 ve Aksaray ilinden 52 olmak üzere toplam 109 olarak bulunmuştur. Elde edilen örnek hacmi, tabakalara oransal olarak dağıtılmıştır. Anket çalışması, Aralık 2018- Ocak 2019 döneminde gerçekleştirilmiştir.

Çalışmada üreticilerin koyun yetiştiriciliği faaliyetine devam etme olasılığını etkileyen faktörlerin belirlenmesinde lojistik regresyon yönteminden yararlanılmıştır. Lojistik regresyon, bağımlı değişkenin kategorik olduğu ve kesikli değerler aldığı durumlarda bağımlı ve açıklayıcı değişkenler arasındaki ilişkinin incelenmesinde tercih edilmektedir. Lojistik regresyon analizinde bağımsız (açıklayıcı) değişkenlerin tamamı ya da bir kısmının sürekli ya da kategorik olması ile ilgili bir zorunluluk bulunmamaktadır (Iş̧ğıçok, 2003). Analizde, normal dağılım varsayımı, süreklilik varsayımı önkoşulu bulunmamakta olup, bağımlı değişken üzerinde açıklayıcı değişkenin etkileri olasılık olarak elde edilmektedir (Lemeshow ve Hosmer, 2000; Özdamar, 2002). En çok olabilirlik ise model tahmininde en çok kullanılan yöntemdir (Çokluk, 2010). Lojistik regresyon modeli, Eşitlik 2'de sunulmuştur (Özdamar, 2002).

$$
P=\frac{e^{\beta_{0}+\beta_{1} X_{1}+\cdots+\beta_{k} X_{k}}}{1+e^{\beta_{0}+\beta_{1} X_{1}+\cdots+\beta_{k} X_{k}}}
$$

Eşitlik 2'de P incelenen olayın gözlenme olasılığını, $\beta 0$ sabit katsayıyı, $\beta$ i her bir bağımsız (açıklayıcı) değişken için tahmin edilecek parametre katsayısını, Xi i'nci bağımsız değişkeni, e ise 2.71 sayısını ifade etmektedir.

Lojistik regresyon modelinde kesikli bağımlı değişkenin tahmin edilen olasılık değerleri 0 ile 1 arasında değişmektedir. Model, sonucu 0 ile 1 arasında herhangi bir değer olarak tahmin eder ve bağımlı değişkenin 1 olma olasılığını belirlemeye çalışır. Çalışmada bağımlı değişken gelecekte koyunculuk faaliyetine devam etmeyi düşünenler bir (1) ve devam etmeyi düşmeyenler ise sıfır (0) olarak alınmıştır.

İncelenen bir olayın olasılı̆̆ının kendi dışında kalan diğer olayların olasılığına oranına ODDS Değeri denir (Çolak, 2002). İncelenen iki farklı olayın ODDS değerlerinin birbirine oranına ise ODDS Oranı denir. Lojistik regresyon denkleminde ODDS Oranı, Exp ( $\beta$ ) olarak ifade edilir. Olasılık oranı (Odds), bir olayın meydana gelme olasılığının 
meydana gelmeme olasılığına oranı (Gujarati, 1999) olduğuna göre; exp ( $\beta p)$ Y değişkeninin Xp değişkeninin etkisi ile kaç kat daha fazla ya da \% kaç oranında fazla gözlenme olasılığına sahip olduğunu belirtir (Girginer ve Cankuş, 2008).

Modelde kullanılan açıklayıcı değişkenlerin belirlenmesinde, literatür taramasıyla birlikte koyunculuk faaliyetinin sürdürülebilirliğinin sağlanmasında etkili olduğu düşünülen demografik, ekonomik ve çevresel faktörler olarak dikkate alınmıştır. Bu aşamada modele eklenecek değişkenlerin seçiminde en iyi uyum iyiliğini veren modele göre karar verilmiştir. Modelin açık fonksiyonu aşağıdaki gibidir:

$K D E O=\beta_{0}+\beta_{1} Y a S_{S}+\beta_{2} M D+\beta_{3} E g i t+\beta_{4} D e n+\beta_{5} C \zeta S+\beta_{6} M S+\beta_{7} Y B Y+\beta_{8} T D G+\beta_{9} K B H B o r c ̧+\beta_{10} P S+\beta_{11} N K+\beta_{12} K D O+\beta_{13} A$ $\dot{I} K+\beta_{14} \dot{I} B+\beta_{15} K P+\beta_{16} B \dot{I}$

Modelin bağımlı değiş̧kenini, işletmelerin koyunculuk faaliyetine devam etme olasıllı̆g (KDEO) ile ifade edilmektedir. Modele açıklayıcı değişken olarak dahil edilen demografik faktörler; işletmecinin yaşı (Yas), medeni durumu (MD), eğitim seviyesi (Egit), deneyimi (Den) ve koyun yetiştiriciliğinde aile işgücünün kullanım oranı (AİK) şeklindedir. Modele açıklayıcı değişken olarak dahil edilen çevresel faktörler; çoban bulmada sorun yaşanması (ÇS), merada otlatma süresi (MS), işletmenin yem bitkisi yetiştirme durumu (YBY), işletmesinde barınak ve/veya çalışanlar için konaklama koşullarında iyileştirme yapma durumu (BKİ) şeklindedir. Modele açıklayıcı değişken olarak dahil edilen ekonomik faktör ise; tarım dışı gelir durumu (TDG), koyun yetiştiriciliği için borçlanma durumu (KYBorc), pazarlama sorunu (PS), koyun yetiştiriciliğinin nispi karlılığı (NK), koyun yetiştiriciliği toplam üretim değeri içerisinde küçükbaş hayvancılık için alınan desteklerin oranı (KDO), toplam tarımsal gelir içerisinde koyunculuk faaliyetinin payı (KP), işletme büyüklük grupları (küçük, orta, büyük) şeklindedir (Çizelge 1). Nispi karlılık koyunculuk toplam üretim değerinin toplam üretim masraflarına oranlanması ile elde edilmiştir.

Çizelge 1. Değişken Tanımları

Table 1. Variable Definitions

\begin{tabular}{|c|c|c|}
\hline \multicolumn{2}{|l|}{ Kod } & Bağımsız Değişkenler ve açıklamaları \\
\hline \multicolumn{2}{|l|}{ Yas } & İşletme sahibinin yaşı (y1l) \\
\hline \multicolumn{2}{|l|}{$\mathrm{MD}$} & İşletme sahibinin medeni durumu (Evli: 1; Bekâr:0) \\
\hline \multicolumn{2}{|l|}{ Egit } & İşletme sahibinin eğitimi (yıl) \\
\hline \multicolumn{2}{|l|}{ Den } & İşletme sahibinin deneyimi (y1l) \\
\hline \multicolumn{2}{|l|}{ ÇS } & Çoban bulmada zorluk yaşama (Evet:1; Hayır:0) \\
\hline \multicolumn{2}{|c|}{ MS } & Bir yılda merada geçirilen süre (gün) \\
\hline \multicolumn{2}{|c|}{ YBY (ref:Evet) } & Yem bitkisi yetiştirme durumu (Evet:1; Hayır:0) \\
\hline \multicolumn{2}{|c|}{ TDG (ref:Var) } & Tarım dışı gelir durumu (Var:1; Yok:0) \\
\hline \multicolumn{2}{|c|}{ KBHBorç(ref: Var) } & Koyun yetiștiriciliği için borçlanma (Var:1; Yok:0) \\
\hline \multicolumn{2}{|c|}{ PS (ref:Evet) } & Koyun yetiștiriciliğinde pazarlama sorunu (Evet:1; Hayır:0) \\
\hline \multicolumn{2}{|c|}{ NK } & Koyun yetiştiriciliği faaliyetinin nispi karı \\
\hline \multicolumn{2}{|c|}{ KDO } & $\begin{array}{l}\text { Küçükbaş hayvancılık desteklerinin toplam koyun yetiştiriciliği üretim değeri içerisindeki } \\
\text { oranı (\%) }\end{array}$ \\
\hline \multicolumn{2}{|l|}{ AIK } & Toplam işgücü kullanımı içerisinde aile işgücünün oranı (\%) \\
\hline & İB_Küçük & İşletmedeki hayvan sayıs1 150 baştan küçük ise "1"; değilse "0" \\
\hline & İB Orta & İşletmedeki hayvan sayıs1 150 baş $\leq$ hayvan sayısı $<300$ bas ise " 1 "; değilse "0" \\
\hline & İB_Büyük & İşletmedeki hayvan sayısı 300 başa eşit ve büyük ise "1"; değilse "0" \\
\hline & Toplam tarımsal gelir içerisinde koyunculuk faaliyetinin payı (\%) \\
\hline \multicolumn{2}{|c|}{ BKİ (ref: var) } & Barınak iyileştirme faaliyeti (Var:1; Yok:0) \\
\hline
\end{tabular}

Araştırmada, iller arasında incelenen değişkenlerin ortalamaları bakımından farklılık olup olmadığı istatistiksel olarak test edilmiştir. Değişkenlerin normal dağılişa uygunluğu Kolmogorov-Smirnov testi ile belirlenmiştir. Değişkenlerin normal dağılış göstermediği saptanmıştır. Buna göre incelenen her iki ildeki yetiştiriciler arasında çalışma kapsamında incelenen değişkenler bakımından fark olup olmadığının belirlenmesi için sürekli ve normal dağılım göstermeyen veriler (yaş, eğitim, deneyim, vb) için MannWhitney U testine tabi tutulurken, kategorik nitelikteki veriler (medeni durum, tarım dişı gelir bulunup bulunmama, vb) için ise Pearson Ki-Kare testi uygulanmıştır (Mann and Whitney, 1947; Pearson, 1900).

\section{Bulgular ve Tartış̧ma}

\subsection{TR71 Bölgesinde koyunculuk işletmelerinin yapısı}


Araştırmada kapsamında görüşülen işletmelerin genel özelliklerine ilişkin tanımlayıcı istatistikler, Çizelge 2'de verilmektedir. Araştırma kapsamında görüşülen işletmelerden koyunculuk faaliyetine devam etmeyi düşünenlerin oranı \%53.5'dir. Modele dahil edilen değişkenlerin iller arasındaki farkın anlamlılığını test etmek amacıyla bağımsız gruplar arası hipotez testleri yapılmıştır. Buna göre işletmecilerin medeni durumu $(p<0.05)$, koyunculuk faaliyetinde aile işgücü kullanım oranı ( $<<0.05)$, merada otlatma süresi $(\mathrm{p}<0.05)$, tarım dışı gelir $(\mathrm{p}<0.05)$, tarımsal gelirde koyunculuğun payı $(\mathrm{p}<0.05)$ ve koyunculuğa yönelik desteklerin koyunculuk üretim değeri içerisinde payı $(\mathrm{p}<0.05)$ bakımından iller arasında farklılık istatistiksel olarak anlamlı bulunmuştur.

Çizelge 2. Değişkenler için tanımlayıcı istatistikler

Table 2. Descriptives statistics for variables

\begin{tabular}{|c|c|c|c|c|}
\hline Veriler & Bölge & Ort. \pm Std.Sp. & Min. & Mak. \\
\hline Koyunculuk Faaliyetine Devam & Niğde & $0.52 \pm 0.50$ & 0 & 1 \\
\hline \multirow[t]{2}{*}{ Etmek İsteyenler } & Aksaray & $0.56 \pm 0.50$ & 0 & 1 \\
\hline & Bölge ortalamas1 & $0.54 \pm 0.50$ & 0 & 1 \\
\hline \multirow[t]{3}{*}{ Yaş } & Niğde & $44.28 \pm 13.01$ & 20 & 67 \\
\hline & Aksaray & $46.26 \pm 10.99$ & 27 & 66 \\
\hline & Bölge ortalamas1 & $45.15 \pm 12.15$ & 25 & 67 \\
\hline \multirow[t]{3}{*}{ Medeni durum (Evli)** } & Niğde & $0.80 \pm 0.41$ & 0 & 1 \\
\hline & Aksaray & $0.94 \pm 0.24$ & 0 & 1 \\
\hline & Bölge ortalamas1 & $0.86 \pm 0.35$ & 0 & 1 \\
\hline \multirow[t]{3}{*}{ Eğitim (yıl) } & Niğde & $6.05 \pm 2.01$ & 5 & 15 \\
\hline & Aksaray & $6.48 \pm 2.69$ & 2 & 15 \\
\hline & Bölge ortalamas1 & $6.24 \pm 2.33$ & 2 & 15 \\
\hline \multirow[t]{3}{*}{ Deneyim } & Niğde & $24.61 \pm 12.74$ & 1 & 50 \\
\hline & Aksaray & $22.42 \pm 12.73$ & 2 & 55 \\
\hline & Bölge ortalamas1 & $23.65 \pm 12.73$ & 1 & 55 \\
\hline \multirow{3}{*}{$\begin{array}{l}\text { Koyunculuk faaliyetinde aile } \\
\text { işgücü kullanım oranı (\%)* }\end{array}$} & Niğde & $84.09 \pm 23.21$ & 37.0 & 100.0 \\
\hline & Aksaray & $73.60 \pm 27.68$ & 22.0 & 100.0 \\
\hline & Bölge ortalamas1 & $79.49 \pm 25.68$ & 22.0 & 100.0 \\
\hline \multirow[t]{3}{*}{ Çoban bulma sorunu yaşayanlar } & Niğde & $0.56 \pm 0.50$ & 0 & 1 \\
\hline & Aksaray & $0.50 \pm 0.51$ & 0 & 1 \\
\hline & Bölge ortalamas1 & $0.54 \pm 0.50$ & 0 & 1 \\
\hline \multirow[t]{3}{*}{ Hayvan sayısı } & Niğde & $231.31 \pm 187.32$ & 26 & 827 \\
\hline & Aksaray & $270.40 \pm 218.65$ & 12 & 1075 \\
\hline & Bölge ortalamas1 & $248.46 \pm 201.68$ & 12 & 1075 \\
\hline \multirow[t]{3}{*}{ Merada otlatma süresi (gün)* } & Niğde & $196.88 \pm 61.38$ & 60 & 300 \\
\hline & Aksaray & $228.60 \pm 57.46$ & 0 & 330 \\
\hline & Bölge ortalamas1 & $210.79 \pm 61.50$ & 0 & 330 \\
\hline Barınak veya konaklama & Niğde & $0.44 \pm 0.50$ & 0 & 1 \\
\hline \multirow[t]{2}{*}{ koşullarının iyileştirmesi } & Aksaray & $0.42 \pm 0.50$ & 0 & 1 \\
\hline & Bölge ortalamas1 & $0.43 \pm 0.50$ & 0 & 1 \\
\hline \multirow[t]{3}{*}{ Tarım dışı gelir** } & Niğde & $0.03 \pm 0.18$ & 0 & 1 \\
\hline & Aksaray & $0.26 \pm 0.44$ & 0 & 1 \\
\hline & Bölge ortalamas1 & $0.13 \pm 0.34$ & 0 & 1 \\
\hline \multirow{3}{*}{$\begin{array}{l}\text { Koyunculuk faaliyeti için } \\
\text { borçlanma }\end{array}$} & Niğde & $0.56 \pm 0.50$ & 0 & 1 \\
\hline & Aksaray & $0.44 \pm 0.50$ & 0 & 1 \\
\hline & Bölge ortalaması & $0.51 \pm 0.50$ & 0 & 1 \\
\hline \multirow{3}{*}{$\begin{array}{l}\text { Tarımsal Gelirde Koyunculuğun } \\
\text { payı* }\end{array}$} & Niğde & $55.97 \pm 31.31$ & 10.0 & 100.0 \\
\hline & Aksaray & $83.38 \pm 22.47$ & 20.0 & 100.0 \\
\hline & Bölge ortalamas1 & $67.99 \pm 30.86$ & 10.0 & 100.0 \\
\hline \multirow[t]{3}{*}{ Pazarlama sorunu } & Niğde & $0.19 \pm 0.39$ & 0 & 1 \\
\hline & Aksaray & $0.14 \pm 0.35$ & 0 & 1 \\
\hline & Bölge ortalamas1 & $0.17 \pm 0.37$ & 0 & 1 \\
\hline \multirow[t]{3}{*}{ Nispi Kar } & Niğde & $1.19 \pm 0.24$ & 0.75 & 1.75 \\
\hline & Aksaray & $1.14 \pm 0.26$ & 0.48 & 2.11 \\
\hline & Bölge ortalamas1 & $1.17 \pm 0.25$ & 0.48 & 2.11 \\
\hline
\end{tabular}




\begin{tabular}{lrrrr}
\hline Yem bitkisi yetiştirme & Niğde & $0.55 \pm 0.50$ & 0 & 1 \\
& Aksaray & $0.54 \pm 0.50$ & 0 & 1 \\
GSÜD içerisinde koyunculuk & Bölge ortalaması & $0.54 \pm 0.50$ & 0 & 1 \\
desteklerinin oranı (\%)* & Niğde & $5.06 \pm 2.20$ & 2.02 & 11.23 \\
& Aksaray & $4.60 \pm 1.57$ & 1.45 & 8.11 \\
& Bölge ortalaması & $4.86 \pm 1.95$ & 1.45 & 11.23 \\
\hline
\end{tabular}

* Mann - Whitney U testine göre ortalamalar arasındaki fark istatistiksel olarak anlamlıdır ( $\mathrm{p}<0.05)$.

**Ki-kare testine göre ortalamalar arasındaki fark istatistiksel olarak anlamlıdır $(\mathrm{p}<0.05)$.

Araştırma kapsamında görüşülen işletmecilerin yaşı 20 ile 67 yaş aralığında değişmekte ve ortalaması 45.15'dir. Araştırma bölgesindeki işletme sahipleri arasında evli olanların oranı \%86 iken, Niğde ilinde \%80, Aksaray ilinde ise \%94'dür. Koyunculuk yapan işletme sahiplerinin ortalama eğitim süresi 6.24 yıl, ortalama koyunculuk deneyimleri 23.65 yıldır. İşletmelerin ortalama koyun varlığı araştırma bölgesinde 248.46 baş, Niğde ilinde 231.31 baş ve Aksaray ilinde 270.40 baştır. Koyunculuk faaliyetinde aile işgücü kullanım oranı bölgede $\% 79.49$, Niğde ilinde \%84.09, Aksaray ilinde ise \% 73.60'dir. Araştırma bölgesindeki işletmelerin \%54'ünün en önemli sorunu çoban bulmada sıkıntı yaşamalarıdır. Merada yılda koyunların otlatıldığı ortalama süre Aksaray ilinde 228.6 gün, Niğde ilinde ise 196.9 gündür. İşletmeler arasında hayvan barınağı ve/veya sürü yöneticisi ve diğer çalışanların konaklama koşullarını iyileştirenlerin oranı \%43'dür. Diğer yandan işlemelerin tarım dışı gelir durumları bakımından farklılıklar dikkat çekicidir. Tarım dışı geliri olanların oranı Niğde ilinde \%3 iken, Aksaray ilinde \%26'dır. Koyun yetiştiriciliği için borç alanların oranı, işletmeler genelinde \%51, Niğde ilinde \%56 ve Aksaray ilinde \%44'dür. Bununla birlikte, koyunculuk faaliyetinde uzmanlaşma Aksaray ilindeki işletmelerde (\%83.38) Niğde iline (\%55.97)'ne göre daha yüksektir. Bununla birlikte, araştırma bölgesi ve her iki ildeki koyunculuk faaliyeti nispi olarak karlı bulunmuştur. Araştırma bölgesinde işletmelerin nispi kar oranları 0.48 ile 2.11 arasında değişmekte olup, ortalaması 1.17'dir. Bütün işletmeler koyunculuğa yönelik verilen desteklemelerden faydalanmakla birlikte, koyunculuk desteklerinin üretim değeri içerisindeki payı \%1.45 ile \%11.23 arasında değişmekte olup, ortalama \%4.86'dir. Koyunculuk işletmelerinin büyük bir çoğunluğu (\%83'ü), pazar sorunu yaşamadığını belirtmiştir. Bölgede işletmelerin yarıdan fazlası (\%54.39’u) ise, yem bitkisi olarak buğday, arpa, çavdar, yonca ve silajlık mısır üretimine yer vermektedir.

\subsection{Lojistik regresyon analizi model sonuçları}

Lojistik modeline dahil edilen değişkenlere ait sonuçlar Çizelge 3'te verilmiştir. Lojistik regresyon analizi model sonuçlarına göre, bağımlı değişken ile bağımsız değişkenler arasındaki ilişkinin yüzdesini gösteren Cox ve Snell R2 ve Nagelkerke R2 istatistikleri sırasıyla \%43.6 ve \%58.2 olarak bulunmuştur. Bununla birlikte, çoklu regresyonda R2'ye karşılık gelen Loglikehood (-2LL) değeri ise 92.184 olarak bulunmuştur. Modelin uyumunu değerlendiren Hosmer ve Lemeshow testinin anlamlılık değeri 0.590 bulunmuş olup, bu değerin 0.05 'ten büyük olması tahmin edilen model ile veri uyumunun iyi olduğunu ve modelin tahmin gücünün yüksek olduğunu göstermektedir. Modelin doğru sınıflandırma yüzdesi ise \%79.8 olarak bulunmuş olup, modelin sınıflandırma gücünün iyi olduğu söylenebilir.

Çizelge 3. Lojistik regresyon model sonuçları

Table 3. Logistic regression model results

\begin{tabular}{|c|c|c|c|c|c|c|c|}
\hline \multirow[b]{2}{*}{ Değişkenler } & \multirow[b]{2}{*}{ Katsay 1} & \multirow{2}{*}{$\begin{array}{c}\text { Standart } \\
\text { Hata }\end{array}$} & \multirow[b]{2}{*}{ Wald } & \multirow[b]{2}{*}{$\mathrm{P}$} & \multirow{2}{*}{$\begin{array}{r}\text { Odds } \\
\text { Oran1 } \\
(\operatorname{Exp}(\mathrm{B}))\end{array}$} & \multicolumn{2}{|c|}{ \%95 Güven Sınırları } \\
\hline & & & & & & Alt & Üst \\
\hline Sabit & -15.563 & 4.112 & 14.323 & $0.000 * * *$ & 0.000 & & \\
\hline Yaş & 0.039 & 0.046 & 0.734 & 0.392 & 1.040 & 0.951 & 1.137 \\
\hline MD (ref:Evli) & 1.616 & 0.959 & 2.844 & $0.092 *$ & 5.035 & 0.769 & 32.954 \\
\hline Eğitim & 0.414 & 0.182 & 5.152 & $0.023^{* *}$ & 1.513 & 1.058 & 2.163 \\
\hline Deneyim & 0.006 & 0.040 & 0.024 & 0.877 & 1.006 & 0.931 & 1.087 \\
\hline ÇS (ref: Evet) & -1.668 & 0.726 & 5.281 & $0.022^{* *}$ & 0.189 & 0.045 & 0.782 \\
\hline MS & 0.011 & 0.006 & 3.413 & $0.065 *$ & 1.011 & 0.999 & 1.022 \\
\hline YBY (ref:Evet) & 1.420 & 0.649 & 4.794 & $0.029 * *$ & 4.137 & 1.161 & 14.748 \\
\hline TDG (ref:Var) & 0.425 & 0.931 & 0.209 & 0.648 & 1.530 & 0.247 & 9.489 \\
\hline KBHBorç(ref: var) & -1.373 & 0.658 & 4.356 & $0.037 * *$ & 0.253 & 0.070 & 0.920 \\
\hline PS (ref:Evet) & -0.204 & 0.803 & 0.064 & 0.800 & 0.816 & 0.169 & 3.935 \\
\hline NK & 2.254 & 1.383 & 2.657 & 0.093* & 9.529 & 0.634 & 143.303 \\
\hline KDO & 0.392 & 0.168 & 5.440 & $0.020^{* *}$ & 1.481 & 1.065 & 2.059 \\
\hline AİK & 0.027 & 0.012 & 4.860 & $0.027 * *$ & 1.028 & 1.003 & 1.053 \\
\hline
\end{tabular}




\begin{tabular}{lrrrlrrr} 
İB_Küçük & & & 1.505 & 0.471 & & & \\
İB_Orta & 0.310 & 0.754 & 0.169 & 0.681 & 1.364 & 0.311 & 5.984 \\
İB_Büyük & -0.637 & 0.746 & 0.730 & 0.393 & 0.529 & 0.123 & 2.281 \\
KP & 0.016 & 0.011 & 2.227 & 0.136 & 1.016 & 0.995 & 1.038 \\
BKİ (ref: var) & 2.640 & 0.708 & 13.923 & $0.000^{* * *}$ & 14.015 & 3.502 & 56.090 \\
\hline${ }^{* * *} p<0.001,{ }^{* *} p<0.05,{ }^{*} p<0.1$ & & & & & & &
\end{tabular}

Model analiz sonuçlarına göre işletmelerin koyun yetiştiriciliği faaliyetine devam etme olasılığına; işletmecinin medeni durumu, merada otlatma süresi ve faaliyetin nispi karlığı değişkeni \%10 düzeyinde istatistiksel olarak anlamlı etkiye sahipken, işletmecinin eğitimi, çoban bulma sorunu yaşaması, yem bitkisi yetiştirme durumu, küçükbaş hayvancılık için borçlanma durumu, küçükbaş hayvancılık desteklerinin üretim değeri içerisindeki payı ve aile işgücü kullanım oranı değişkenleri \%5 düzeyinde istatistiksel olarak anlamlı etkiye sahiptir. İşletmelerin barınak veya konaklama yerlerinde iyileştirme yapma durumu değişkeni ise \%1 düzeyinde istatistiksel olarak anlamlı bulunmuştur.

Medeni durumu evli olanların bekâr olanlara göre koyun yetiştiriciliğine devam etme olasılı̆g 15.03 kat daha fazladır. Araştırmanın saha çalışması sırasında yapılan gözlemlerde, araştırmaya dahil olan işletmelerde medeni durumu bekar olan yetiştiricilerin \%68.8'i koyunculuk ve çobanlık mesleğinin evlenme çağındaki kadınlar tarafından kabul görmemesi endişesi yüzünden gelecekte bu faaliyeti yapmak istemediklerini belirtmişlerdir.

Eğitim seviyesi artıkça yetiştiricilerin koyunculuk faaliyetini devam ettirme olasılığının 1.51 kat arttığı belirlenmiştir. Çiftçinin eğitim seviyesinin artışı tarımda kalma eğilimini pozitif ya da negatif olarak etkileyebilmektedir. Şöyle ki; Panda (2015) ve Altıntaş ve ark. (2019)'nın çalı̧̧malarında çiftçinin eğitim seviyesi artıkça işletmecilerin daha iyi şartlarda iş bulma ve yaşam standardı yakalama isteğinden dolayı tarımdan vazgeçme eğiliminin arttığını ortaya koymuşlardır. Buna karşın, Alassaf ve ark. (2011)'nın çalışmasında çiftçilerin eğitim seviyesinin artması işletmelerinin daha iyi yönetilerek verimliliğin ve karlılığının arttırılmasının etkisiyle tarımsal faaliyetlerini sürdürmelerine olumlu etkisi olduğunu ortaya koymuşlardır.

Koyunculuk faaliyetinin sürdürülebilirliğinin sağlanmasında en temel sorunların başında çoban bulma sıkıntısı gelmektedir (Aksoy ve Yavuz, 2012). Aynı sorun, araştırma sonuçlarıyla benzerdir. Çalışmada çoban bulmada sorun yaşayanların koyunculuk faaliyetini devam ettirme olasılığ $1 \% 81.1$ daha düşük olduğu görülmüştür. Genç nüfusun kırsaldan kente göç etmesi ve köyde kalan gençlerin ise koyunculuk faaliyetini zahmetli bir faaliyet olarak görmesi ve çobanlığın sosyal bir güvencesinin olmaması nedeniyle meslek olarak görülmemektedirler. Yaşlı yetiştiriciler ise yüksek maaşlarla bile çoban bulamamaları nedeniyle koyun yetiştiriciliği faaliyetinden vazgeçmektedirler.

İşletmelerde yem bitkisi yetiştirilmesi koyunculuk faaliyetine devam etme olasıllığını 4.14 kat artırmaktadır. Dağıstanlı (2002)'nın koyunculuk faaliyetinin ekonomik analizini yaptığı araştırmasında, değişken masrafların işgücünden sonra en önemli girdi kalemini yem masraflarının oluşturduğu belirtmektedir. Özellikle verimsiz ve ot kalitesi düşük meralardan koyunların kaba yem ihtiyacının yeterince karşılanamadığı durumlarda işletmeler kaba yem açığını dışarıdan satın alarak sağlanmaktadırlar. Bu durum ise üretim maliyetleri içerisinde yem masraflarının yükselmesine neden olmaktadır. Buna karşın, yem bitkisi yetiştiren işletmeler, yem maliyetlerini düşürerek karlılığını artırabilmektedir. Küçükbaş hayvan yetiştiriciliği için borçlanan işletmelerin bu faaliyeti devam ettirme olasılığı \%74.7 oranında azalmaktadır. Çalışmadan elde edilen bulgular literatürle de uyumludur. Gürbüz ve Gül (2016), süt sığırcılığı işletmelerinde finansman kaynakları ile hayvancılığa devam etme kararları arasında istatistiki olarak olumlu bir ilişki bulmuş ve öz kaynaklarını kullanan işletmelerin hayvancılığa devam etme eğilimi işletme dışından finansal kaynak kullananlara göre daha fazla olduğunu saptamıştır. İşletme faaliyetinin çiftçiler tarafından sürdürülebilirliğinin sağlanmasında en temel ekonomik belirleyicilerinden birisi ise şüphesiz faaliyetin karlılığıdır. Nitekim çalışmada işletmelerin koyunculuk faaliyetine devam etme olasılığ üzerinde en etkili ekonomik faktörlerin başında da üretim faaliyetinin nispi karlılığı olduğu bulunmuştur. Buna göre nispi karlılığın bir birim artması, işletmeler tarafından bu faaliyeti devam ettirme olasılı̆̆ını 9.53 kat arttırmaktadır. Elde edilen sonuç, literatürdeki çalışmalarla da uyumludur (Bragg ve Dalton 2004; Peel et al. 2016).

Koyunculuk faaliyetinin toplam üretim değeri içerisinde küçükbaş hayvancılık desteklerinin oranın artması, işletmelerin koyunculuk faaliyetini devam ettirme olasılığını pozitif yönde etkilemektedir. Buna göre üretim değeri içerisinde desteklerin payının bir birim artması, bu faaliyeti devam ettirme olasılığını 1.48 kat artırmaktadır. Bu sonuç, tarımsal desteklerin çiftçilerin tarımda kalma eğilimini artııdığını ortaya koyan diğer literatür çalışmalaryla da uyumludur (Goetz ve Debertin, 2001; Breustedt ve Glauben, 2007; Torgur ve ark., 2019).

Koyunculuk faaliyetinde aile işgücünün kullanımı, özellikle küçük aile işletmelerinde faaliyetin sürdürülebilirliği açısından en önemli unsurlardan birisidir. Beklentiye uygun olarak, çalışma kapsamında koyunculuk faaliyetinde yoğun olarak kullanılan toplam işgücü içerisinde aile işgücü kullanım oranı ise bu faaliyeti devam ettirme olasılığı üzerinde pozitif etkisi olduğu bulunmuştur. Koyunculuk faaliyeti özellikle yoğun işgücü gerektirmesi nedeniyle işgücü maliyetini düşürmek için özellikle aile üyeleri tercih edilmektedir. Bu durum ise aile işgücünün daha yoğun kullanıldığı işletmelerde nakit masrafların düşürülmesi açısından diğer işletmelere göre firsat olarak görülmektedir. Literatürde aile işgücünü kullanan işletmelerin tarıma devam etme olasılığını arttırdığını ortaya koyan çalışmalar da 
mevcuttur (Glauben et al. 2004; Ahmad et al. 2020). Ayrıca, işletmelerde hayvan barınak ve/veya çalışanların konaklama yerlerinde iyileştirme faaliyeti yapan işletmelerin koyunculuk faaliyetini devam ettirme olasılığ 14.01 kat artığı bulunmuştur. Koyun yetiştiriciliğinde çevre koşullarının iyileştirilerek uygun barınma ortamlarının sağlanması, üretimin devamı açısından önemlidir (Karaman ve ark., 2012). Çalışmanın saha çalışması kısmında özellikle Niğde ilindeki barınakların geleneksel yapıların ve hatta bazı yerlerde mağara gibi doğal yapıların barınak olarak kullanıldığı gözlenmiştir. Benzer durum yılın ortalama 7 ile 8 ayını merada geçiren işletmeci ve/veya çalışanların konaklama yerlerinde su, elektrik, iletişim gibi ciddi altyapı sıkıntılarının olduğu da gözlemlenmiştir. Bu açıdan bakıldığında işletmelerde barınak ve konaklama koşullarının iyileştirilmesi, analiz kapsamında koyunculuk faaliyetinin devam ettirilmesinde en etkili faktör olduğu bulunmuştur.

Çalışmada merada otlatma süresi ile bu faaliyeti devam ettirme olasılığı arasında pozitif bir ilişki bulunmuştur. Meralarda çok çeşitli yem bitkileri bulunduğundan, besin değeri yüksektir. Meralar ayrıca yem maliyetlerini düşürdükleri için ekonomik bir değere sahiptir. Kaba yemler ve özellikle meralar, koyunların beslenme ihtiyaçlarını karşılamada önemli bir yere sahiptir. Bu nedenle koyun yetiştiriciliğinde birincil yem kaynağı olarak tercih edilmektedir. Bununla birlikte, meradaki kısa otlatma süresi ve bitki örtüsüne bağlı düşük besin değeri de hayvanlardan istenen verimi alınması engellemektedir.

\section{Sonuç ve Öneriler}

Türkiye'de giderek artan kırmızı et açığı nedeniyle küçükbaş hayvancılık ve özellikle koyun yetiştiriciliği faaliyetinin devam ettirilmesi stratejik bir öneme sahiptir. Koyunculuk faaliyetinin iklim koşullarına uyum yeteneğinin yüksekliği, meraya dayalı bir besleme nedeniyle yem giderlerinin düşüklüğü, üreme yeteneği ve verime geçiş sürecinin kısalığı ile sabit yatırım giderlerinin nispeten düşük olması, bu faaliyetin önemini daha da artırmaktadır. Bu kapsamda ülke içerisinde 1.73 milyon baş hayvan varlı̆̆ ile önemli bir potansiyele sahip TR71 bölgesi, koyun yetiştiriciliği konusunda geniş bir yetiştiricilik kültürüne sahip olmasına rağmen, bu faaliyet alanında ulusal gelişmelere paralel olarak uzun yıllardır kayda değer bir gelişme sağlanamamıştır. Son on yılda sektöre sağlanan desteklerle ayakta tutulmaya çalışılan koyun yetiştiriciliğinin ekonomik yönü ile birlikte demografik ve çevresel sorunlarının da bütüncül bir yaklaşımla ele alınması gerekmektedir. Bu çalışmada, TR71 Bölgesindeki koyunculuk işletmelerinin faaliyetlerini devam ettirme kararları ve buna etkili olan ekonomik, çevresel ve demografik faktörlerin belirlenmesidir.

Çalışma sonucuna göre işletmelerin bu faaliyeti devam ettirme olasılığına olumlu etki eden ekonomik faktörler arasında faaliyetin nispi karlılığ 1 ve koyun yetiştiriciliğinin toplam üretim değeri içerisinde alınan desteklerin oranı bulunurken, demografik faktörler arasında ise işletmecinin medeni durumu (evli olması), eğitim seviyesinin yükselmesi, aile işgücünün kullanımının artması bulunmuştur. Bununla birlikte, koyun yetiştiriciliği faaliyetinin sürdürülmesinde olumlu etkisi olan çevresel faktörler arasında ise işletmelerde barınak koşullarında iyileştirmenin yapılması başta olmak üzere yem bitkisi yetiştirme durumu ve merada kalma sürelerinin artması bulunmuştur. Diğer yandan bu faaliyetin sürdürülebilirliğini olumsuz etkileyebilecek faktörler arasında ekonomik faktör olarak işletmenin küçükbaş hayvancillk için borçlanma durumu ve çevresel faktör olarak ise çoban bulma sorunu olduğu bulunmuştur.

Çalışma sonuçlarına göre işletmecilerin koyun yetiştiriciliği faaliyetini devam ettirme olasılıkları üzerinde en etkili faktörün işletmelerde barınak ve konaklama koşullarında yapılan iyileştirme yapılması bulunmuştur. Çalışma sonucunda işletmelerin bu faaliyeti devam ettirmelerinde çevresel ve demografik faktörlerin daha ön plana çıktığı görülmüştür. Tüm bu sonuçlar, sektöre yönelik kalkınma modelinin geliştirilmesinde önemle dikkate alınması gereken konulardır. Bu kapsamda özellikle işletmelerde sürü yöneticisi ve diğer çalışanların hayatını kolaylaştıracak konaklama altyapısının oluşturulması, aynı zamanda hayvan refahını gözeten barınak altyapılarının iyileştirilmesi üzerinde hassasiyetle durulması gerekli bir konudur.

Diğer yandan, sektörde en temel sorunların başında gelen özellikle büyük işletmelerde çoban temini konusunda ise bu alanda verilecek eğitimler ile nitelikli sürü yöneticisi yetiştirme programları düzenlenmesi, aynı zamanda bu alanda istihdam edilecek kişilerin sosyo-ekonomik haklarının iyileştirilmesine yönelik düzenlemelere yer verilmesi son derece önemlidir. Özellikle genç nüfusun bu alanda yetiştiricilik yapmasına yönelik teşvik ve destekleme mekanizmaları üzerinde durulmalıdır. Bununla birlikte, çalışmada yetiştiricilerin eğitim seviyelerinin geliştirilmeleri, koyunculuk faaliyetini devam ettirme olasılığı üzerinde olumlu katkısı olduğu görülmüştür. Bu kapsamda yetiştiricilerin alanı ile ilgili güncel gelişmeleri takip edebilmeleri ve teknoloji kullanımını artırılabilmeleri için işletmecilerin özellikle bakım besleme gibi konularda eğitim seviyelerinin geliştirilmesine yönelik programların düzenlemesine ve yetiştiricilerin de bu programlara katılımlarının teşvik edilmesi sağlanmalıdır. Bu kapsamda özellikle yetiştiricilerin koruyucu hekimlik konusunda ve geleneksel yetiştirme ve beslemeden bilinçli yetiştirme ve beslemeye geçmeleri konusunda bilgilendirilmeleri işletmelerin verimliliğinin artırılması açısından önemlidir.

Ayrıca, koyun yetiştiriciliği faaliyetinde bulunan işletmelerin daha çok küçük aile işletmesi niteliğinde ve sermaye yapısı yetersiz işletmelerden oluştuğu dikkate alındığında işletmelerde ölçeğin büyütülmesi veya teknolojik yeniliklerin kullanılması için işletmelerin yeterli tasarruf yapma imkânları bulunmamaktadır. Bu nedenle birçok 
üretici zaman zaman işletme dışı finans kaynaklarına başvuru yapmaktadır. Ancak zamanı geçen borçların ödenmesinde canlı demirbaş hayvanların satılması işletmelerde üretim araçlarını hızlı bir şekilde kaybetmesine ve üretimden çekilmelerine neden olmaktadır. Bu nedenle özellikle küçük aile işletmelerine yönelik kredi ve hibe imkânlarından faydalanabilecekleri programlar üzerinde çalışılması gereklidir.

Koyun yetiştiriciliği faaliyetinin devam ettirilmesinde yetiştiriciler tarafından meraların kullanımı oldukça önemli husustur. Ancak gerek merada otlatma süresinden kaynaklı sorunlar gerekse meraların bitki örtüsüne bağlı düşük besin değeri nedeniyle hayvanlardan arzu edilen verimin alınamamasından dolayı bu faaliyetinden beklenen ekonomik fayda da alınamamaktadır. Bu nedenle sektörün rekabet gücünün artırılmasında mera varlığı ve kalitesi büyük bir avantaj yaratmaktadır. Bu kapsamda meraların planlı otlatılması ve mera 1slahına yönelik çalışmalar bu açıdan önemlidir. Ayrıca meraların kullanılamadığı dönemlerde yetiştiricilerin, işletmesinde yem bitkisi ekimine yer verilmesinin teşvik edilmesine yönelik çalışmalar da bu açıdan önemli olduğu düşünülmektedir.

Buna ek olarak, çalışmada küçükbaş hayvancılık desteklerinin koyunculuk faaliyetini devam ettirilmesinde olumlu etkisi olduğu görülmüştür. Bununla birlikte hali hazırda koyun sayısına göre verilmekte olan küçükbaş hayvancılık desteklemelerinin ise işletmelerde verimi artıracak şekilde uygulanmasının önemli olduğu düşünülmektedir. Bu kapsamda desteklerin koyun sayısından ziyade işletmelerde verim artışını zorlayacak şekilde belirli bir yaş üzerindeki kuzu sayısına göre verilmesi önerilmektedir.

\section{Teşekkür}

Bu çalışma Niğde Ömer Halisdemir Üniversitesi, Bilimsel Araştırma Projeleri Koordinasyon Birimi tarafından desteklenen FEB2017/26-BAGEP No’lu proje verilerinden derlenmiştir.

\section{Kaynaklar}

Agrawal, B., Agrawal, A., 2017. Do farmers really like farming? Indian farmers in transition. Oxf. Dev. Stud., (45): 460-478. Doi: 10.1080/13600818.2017.1283010.

Ahmad, M.I., Oxley, L., Ma, H., 2020. What makes farmers exit farming: a case study of Sindh Province, Pakistan. Sustainability, 12 (8): 3160. Doi: 10.3390/su12083160 (Erişim tarihi: 20.05.2020).

Aksoy, A. ve Yavuz, F., 2012. Çiftçilerin küçükbaş hayvan yetiştiriciliğini bırakma nedenlerinin analizi: Doğu Anadolu Bölgesi örneği. Anadolu Tarım Bilimleri Dergisi, 27(2):76-79s. Doi: 10.7161/anajas.2012.272.76.

Alassaf, A., Majdalwi, M. and Nawash, O., 2011. Factors affecting farmer's decision to continue farm activity in marginal areas of Jordan. African Journal of Agricultural Research 6(12): 2755-2760, Available at: doi: 10.5897/AJAR11.481 (Erişim tarihi: 15.05.2020). Doi: 10.5897/AJAR11.481.

Altıntaş, G., Altıntaş, A., Bektaş, H., Çakmak, E., Oruç, E., Kızılaslan, H., Birol, D., 2019. Genç çiftçi desteklemelerinin gençlerin tarımda kalma eğilimleri üzerine etkileri: TR-83 Bölgesi örneği. Turkish Journal of Agriculture - Food Science and Technology, 7(10): 1682-1693. Doi: 10.24925/turjaf.v7i10.1682-1693.2813.

Başer, U., Bozoğlu M., Kılıç Topuz, B., 2017. Tarım işletmelerinde çevresel, ekonomik ve sosyal sürdürülebilirliğin ölçülmesi. Akademia Mühendislik ve Fen Bilimleri Dergisi, 2(3):1-13.

Bozoglu, M.; Saglam, O.; Topuz, B.K., 2017. Economic sustainability of family dairy farming within the scope of technical efficiency: a case study of Bafra District, Turkey. Custos e @gronegócio on line, 13(2): 2017. 295-316.

Bragg, L.A., Dalton, T.J., 2004. Factors affeting the decision to exit dairy farming: a two-stage regression analysis. Journal of Dairy Science. 87 (9):3092-3098. Doi: 10.3168/jds.S0022-0302(04)73444-X.

Breustedt, G., Glauben, T., 2007. Driving forces behind exiting from farming in Western Europe. J. Agric. Econ., (58): 115-127. Doi: 10.1111/j.1477-9552.2007.00082.x

Ceyhan, A., Şekeroğlu, A., Ünalan, A., Çınar, M., Serbestler, U., Akyol E., Yılmaz, E., 2015. Niğde ili koyunculuk işletmelerinin yapısal özellikleri ve sorunları üzerine bir araştırma. KSÜ Doğa Bilimleri Dergisi., 18(2). Doi: 10.18016/ksujns.10904.

Çokluk, Ö., 2010. Lojistik regresyon analizi: kavram ve uygulama. Kuram ve Uygulamada Eğitim Bilimleri, 10 (3):1357-1407.

Çolak, E., 2002. Koşullu ve sınırlandırılmış lojistik regresyon yöntemlerinin karşılaştırılması ve bir uygulama. (Basılmamış Yüksek Lisans Tezi) Osmangazi Üniversitesi, Eskişehir.

Çukur, T., 2016. Milas ilçesinde süt sığırcılığı yapan çiftçilerin tarımda kalma eğilimlerinin belirlenmesi. XII. Tarım Ekonomisi Kongresi Bildiri Kitab1 (25-27 Mayis 2016). Isparta.

Dağıstanlı, E., 2002. Orta-Güney Anadolu Bölgesi’nde koyunculuk faaliyetinin ekonomik analizi. Ç.Ü. Fen Bilimleri Enstitüsü Doktora Tezi. Tez No:119827. 198 syf. Adana.

FAO, 2020. FAOSTAT (Canlı Hayvan İstatistikleri). www.fao.org/faostat. (Erişim Tarihi: 18.05.2020).

Girginer, N., Cankuş, B., 2008. Tramvay yolcu memnuniyetinin lojistik regresyon analizi ile ölçülmesi: Estram örneği. Yönetim ve Ekonomi, 15(1):181-193. 
Glauben, T., Tietje, H. and Weiss, C., 2004. Intergenerational succession in farm households: Evidence from upper Austria. Review of Economics of the Household, (2): 443-461.

Goetz, S.J., Debertin, D.L., 2001. Why farmers quit: a county-level analysis. American Journal of Agricultural. Economics, (83):1010-1023.

Gujarati, D.N., 1999. Temel ekonometri. (Çev. Ü.Şenesen ve G.G. Şenesen), Literatür Yayıncıllk, İstanbul.

Gürbüz, D. ve Gül, M., 2016. Süt sığırcıllı̆ı işletmelerinde finansman kaynakları: Burdur ili örneği. Mustafa Kemal Üniversitesi Ziraat Fakültesi Dergisi, 21(1):57-70.

Işığıçok, E., 2003. Bebeklerin doğum ağırlıklarını ve boylarını etkileyen faktörlerin lojistik regresyon analizi ile araştırılması. Ankara, VI. Ulusal Ekonometri ve İstatistik Sempozyumu Bildiri Kitabı, Gazi Üniversitesi İ.İ.B.F. Ekonometri Bölümü.

Kan, A., Kan, M., Doğan, H.G., Tosun, F., Uçum, İ., ve Solmaz, C. 2018. Evaluation of young farmers Project support program in terms of agri-entrepreneurship in Turkey. Pak.J.Agr.Sci. 55 (4):1021-1031. Doi: 10.21162/PAKJAS/18.7321.

Karaman, S., Ulutaş, Z., Şirin, E., Aksoy, Y., 2012. Tokat yöresindeki ağılların yapısal ve çevre koşulları yönünden durumu ve geliştirme olanakları üzerine bir araştırma. GOÜ Ziraat Fakültesi Dergisi, 29 (2):29:41.

Keskinkılıç, K., 2019. Koyunculuk faaliyetinin sürdürülebilirliği. İzmir Ticaret Borsası Yayınları Yayın No:99. İzmir. ISBN:978-605-137-740-7.

Kimhi, A., Bollman, R., 1999. Family farm dynamics in Canada and Israel: The case of farm exits. Agric. Econ. (21):69-79. Doi: 10.1016/S0169-5150(99)00015-8.

Koca, A., 2014. Karaman ilinde koyunculuk üretim faaliyetine yer veren işletmelerin yapısal analizi. Selçuk Üniversitesi Fen Bilimleri Enstitüsü, Yüksek Lisans Tezi. 85 Syf. Konya.

Koç, G., Uzmay, A., 2019. Trakya Bölgesi üreticilerinin süt sığırcıllğı faaliyetinden vazgeçme olasıllğını etkileyen faktörler. Tarım Ekonomisi Dergisi, 25(1):41-52. Doi: 10.24181/tarekoder.538942.

Lemeshow, S., and Hosmer, D., 2000. Applied logistic regression (Wiley Series in Probability and Statistics). WileyInterscience; 2 Sub edition .p.2-4

Mann, H.B. and Whitney, D.R., 1947. On a test of whether one of two random variables is stochastically larger than the other. Annals of Mathematical Statistics, 18(1):50-60.

Mishra, A.K., Fannin, J.M., Joo, H., 2014. Off-farm work, intensity of government payments, and farm exits: Evidence from a national survey in the United States. Can. J. Agric. Econ. Rev., (62):283-306. Doi: 10.1111/cjag.12027.

Özdamar, K., 2002. Paket programlar ile istatistiksel veri analizi. Cilt 1, 2.Baskı, Kaan Kitabevi, 475-477 Eskişehir.

Özsayın, D., ve Everest, B., 2019. Koyun yetiştiriciliği yapan üreticilerin sosyo-ekonomik yapısı ve koyunculuk faaliyetiyle ilgili uygulamaları. KSÜ Tarım ve Doğa Dergisi, 22 (Ek Sayı 2): 440-448. Doi: 10.18016/ksutarimdoga.vi.589725.

Panda, S., 2015. Farmer education and household agricultural income in rural India. Int. J. Soc. Econ., (42):514-529. Doi: 10.1108/IJSE-12-2013-0278.

Pearson, K, 1900. On the criterion that a given system of deviations from the probable in the case of a correlated system of variables is such that it can be reasonably supposed to have arisen from random sampling. Philos. Mag., (50): 157-175.

Peel, D., Berry, H.L., and Schimer J., 2016. Farm exit intention and wellbeing: A study of Australian farmers. Journal of Rural Studies, 47(2016): 41-51. Doi: 10.1016/j.jrurstud.2016.07.006

Pietola, K., Väre, M., Lansink, A.O., 2003. Timing and type of exit from farming: Farmers' early retirement programmes in Finland. Eur. Rev. Agric. Econ., (30):99-116. Doi: 10.1093/erae/30.1.99

Pokhrel, K.P., Sharaf, T., Bhandari, P., Ghimire D., 2020. Farm exit among smallholder farmers of Nepal: A bayesian logistic regression models approach. Agricultural Research. Doi:10.1007/s40003-020-00465-4.

Sav, O., Sayın, C., 2018. Tarımda kalma eğilimini etkileyen başlıca faktörlerin genel bir değerlendirmesi. KSÜ Tarım ve Doğa Dergisi, 21 (Özel Sayı):190-197. Doi: 10.18016/ksutarimdoga.vi.4728903.

Şahinli, M.A., 2011. Konya ilinde koyunculuk faaliyetine yer veren tarım işletmelerinin ekonomik analizi ve koyunculuk faaliyetinde etkili olan unsurların saptanması. Ankara Üniversitesi, Fen Bilimleri Enstitüsü, Doktora Tezi. 205 syf. Ankara.

Torgur, E., Annayev, S., Türkekul, B., Örmeci Kart, M.Ç., 2019. Türkiye'de uygulanmakta olan hayvancilık desteklemelerinin süt sığırcılığı yapan işletmelere etkisi: İzmir ili örneği. Ziraat Fakültesi Dergisi, 14 (1):29-45.

TÜIK, 2020. Hayvancılık İstatistikleri. Türkiye İstatistik Kurumu. http://tuik.gov.tr/PreTablo.do?alt_id=1002 (Erişim Tarihi: 12.05.2020).

Uysal, Ö.K., 2015. Manisa ili Yunt dağı köylerinde çiftçilerin tarımsal üretime yaklaşımlarını etkileyen faktörlerin analizi. Sosyal ve Beşerî Bilimler Araştırmaları Dergisi, Güz, (35):76-99.

Yamane, T., 1967. Elementery Sampling Theory Prentice. Hall Inc, Englewood Cliffs, 405 p., N.J., USA. 